\title{
明治期の浜松医者屋敷と庭園の建設過程に関する研究 A STUDY ON THE CONSTRUCTION PROCESSES OF THE CLINIC AND GARDEN IN HAMAMATSU DURING THE MEIJI PERIOD
}

\author{
鈴木里 佳*, 三 浦 彩子** \\ Rika SUZUKI and Ayako MIURA
}

\begin{abstract}
Teiji Uchida, a doctor in Hamamatsu City during the Meiji period wrote fourteen volumes of diary named "Meiji-nenchu-zatsuroku" (thirteen exist today). This paper describes the process of the construction of his clinic facilities including the gardens by looking up the whole volume of the documents.

1. Five buildings and accompanying gardens were constructed at the start of the clinic around $20^{\text {th }}$ year of Meiji. Construction of the buildings and gardens seems to be done in the same period.

2. Kuwakichi Takahashi was in charge of the construction. He was also commissioned of "wood construction" of the local temple. He expanded business to real estate area and was concerned with the later expansion of the premises.

3. Niwahei was in charge of gardens. He was a well-known gardener of the district. He dedicated himself to the project making trips with the client seeking the desirable trees.
\end{abstract}

Keywords : Teiji Uchida, Clinic, Construction process, Gardener, Hamamatsu, The Meiji era 内田貞二，診察所，建設過程，庭師，浜松，明治時代

\section{1.はじめに}

内田貞二 ${ }^{11}$ は、明治時代に現在の浜松市中区新町の旧東海道沿い で開業した蘭方医であり、安政のコレラ流行期の感染予防書である 『防疫貴目』や、幕政の天保の改革に対する政策批判を述べた書物 である『破地士等窠』の作者としても知られる。

開業当時の診察所および屋敷内の様子は、明治 20 年代の農・工・ 商家の邸宅や神社、仏閣、名所旧跡、学校などの銅版画を収録した 『静岡県明治銅版画風景集』から推察することができる。さらに、 内田貞二は明治 14 年から 32 年 (1881〜 1899) までの 18 年間にわた り、総数 14 冊に及ぶ『明治年中雜録』を書き残しており、これらは 現在、浜松市立中央図書館に所蔵されている。

『明治年中雜録』はこれまでに、診客録や、医師会の議事録など、 主に医院業務に関する内容が紹介されており ${ }^{3)}$ 、内田貞二の晚年期 の日記風の手控とされてきた。しかし同時に、屋敷修繮に従事した 職人の施工日時や内容、職人名、報酬金額も記録されており、施主 である貞二が、発注工事の作業の進行状況から従事者の人工数など を書き留める目的があったと捉えられる。そこで本研究では、『明治 年中雜録』を屋敷や庭園管理に関する詳細な工事記録であるとして 再評価を行い、建築と庭園の建設過程を明らかにするものである。

\section{2.『明治年中雜録』について}

『明治年中雜録』は、寸法縦 $34.0 \times$ 横 $12.6 \mathrm{~cm}$ の和装本であり、 美濃判和紙を横に細長く二ッ折りにして、 1 冊につき約 60 枚が綴じ られている。冊数は、『明治年中雜録 壹』から『明治年中雜録 拾 肆』までの 14 冊から成る（図 1)。保存状況は、一部、虫損の著し い箇所があるものの全体的に良好であるが、『明治年中雜録 拾参』 を欠失している。作成時期は、明治 14 年 8 月 31 日から明治 32 年 2 月 26 日までの約 18 年間にわたるもので、表 1 (『明治年中雜録』各 巻内容一覧)として、各巻の作成時期と丁数、それぞれの記載事項を 整理した。『明治年中雜録』の内容は、来客の覚書や、日常的な屋敷 管理・庭園管理に関する文章であり、これらは「七月廿八日午後一 時半頃ヨリ庭平小安」と、日付を付した後、職人名を連記した表記 法である。従って『明治年中雜録』の原文の解読から、明治 14 年か ら 32 年までの期間における内田家 ${ }^{4)}$ の屋敷修繥に従事した職人の 施工日時や施工内容、報酬金額の詳細が判明する。また後述するよ うに『明治年中雜録 参』には地租改正下調帳の一部写しや、土地 売買についての記載があり、土地の購入経緯や、凡その規模や形状 の推定が可能である。この他に、曹洞宗松屋山萬福寺 ${ }^{5}$ に関する事 項が見られ、『明治年中雜録』は、寺院の修復、小作納記、自邸の屋
$*$ 名城大学大学院理工学研究科 博士後期課程 $\cdot$ 工修
$* *$ 名城大学理工学部建築学科 助 $\cdot$ 博
Doctoral Course, Graduate School of Science and Engineering, Meijo Univ., M. Eng. Assistant Prof., Dept. of Architecture, Faculty of Science and Technology, Meijo Univ., Dr. Eng. 


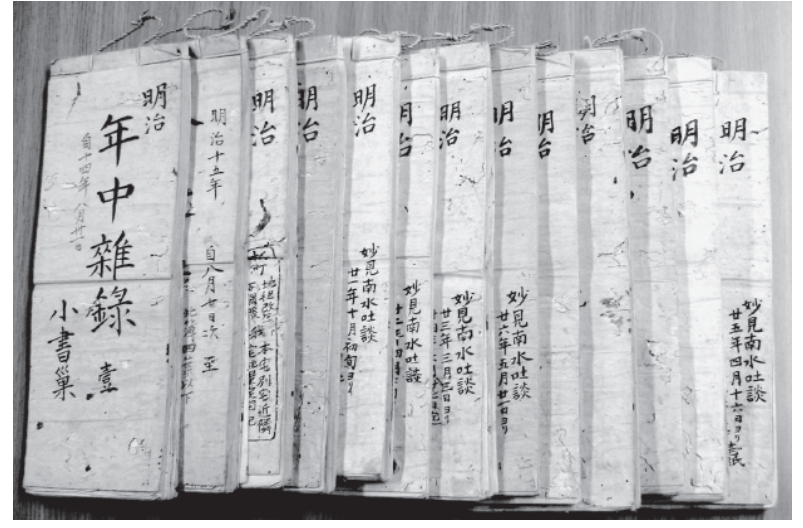

図 1 『明治年中雜録』全巻表紙 $\left.{ }^{6}\right)$ (写真左より壹巻)

敷管理、庭園管理、地租改正といった、明治中頃の地方情勢の具体 的動向を知る上でも重要な史料である。

以上に述べた『明治年中雜録』の現存する全 13 冊の内容から、内 田家の屋敷及び庭園に関する主要な原文や絵図を抜き出し、次章以 降で屋敷の新築・補修を含めた建設経緯と造園内容を明らかにする。

\section{3. 屋敷地の成立過程}

\section{1 内田家屋敷に関する絵図資料}

内田家の屋敷は、浜松城より東方向の敷知郡濱松町新 (現在の静岡 県浜松市中区新町) に位置する。屋敷は、後に家督を継いだ貞二の長 男である内田正に継承されたが、第二次世界大戦時に一帯は焼失し ている ${ }^{7)}$ 。東海道沿いの、江戸時代から町屋が形成される、城下町 に近い地区にあったが ${ }^{8)}$ 、明治時代の内田家の屋敷構えの様子を、 図 2 に示した『静岡県明治銅版画風景集』に掲載された銅版画から 推察することができる。この文献に関する既往研究には、銅版画に 描かれた屋敷林に着目して、静岡県の伝統的な樹木構成を分析した 研究 ${ }^{9)}$ がある。その他、銅版画から日除けの形状を集計して、その

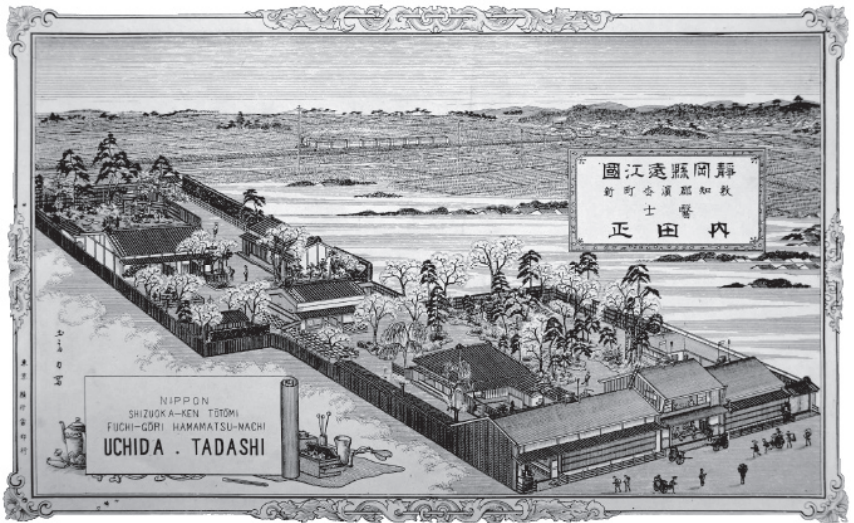

図 2 内田正邸 (『静岡県明治銅版画風景集』より抜粋)

発生と普及について考察した研究 ${ }^{10)}$ 、銅版画と建築写真との照合か ら、銅版画の描写の内容が極めて正確であることを確認し、明治期 の小学校について考察した研究 ${ }^{11}$ などがある。

本研究で分析する『静岡県明治銅版画風景集』は、静岡県の全工 リアにある 369 件の寺院・個人邸宅の鳥瞰図を収録したものである。 この中の「静岡縣遠江國敷知郡濱昙町新 醫士 内田正」と題した 銅版画には、往来のある東海道側を正面とした細長い敷地内に、大 小合わせて 8 棟の建物の他、桜樹を多く配植させた庭園が鳥瞰図風 に精密に描写されている。この内田家銅版画に関連する記述を、以 下の『明治年中雜録 別』の明治 24 年 8 月 1 日の原文において確認 することができる。

(1)『明治年中雜録 別』(明治 24 年 8 月 1 日の原文より拔粋) 宅舎図 八月一日画工両人来寫其大略

これは明治 24 年 8 月 1 日に、画工が「宅舎図」すなわち、屋敷内 の建物図面の写しを行ったことを述べた内容であるが、その目的に

表 1 『明治年中雜録』各巻内容一覧

\begin{tabular}{|c|c|c|c|}
\hline 史料名称 & 年月日 & 丁数 & 主な内容 \\
\hline 『明治年中雜録 壹』 & 明治14年8月31日 & 60 & 来客、屋敷管理、庭園管理、萬福寺関連、小作納記、第四醫區研習會、政治経済、周平箋、正児箋、畑地賣渡/証 \\
\hline 『明治年中雜録 武』 & 明治15年12月13日 & 57 & 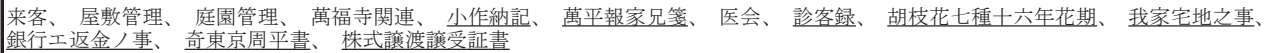 \\
\hline 『明治年中雜録 参』 & 明治17年9月1日 & 59 & 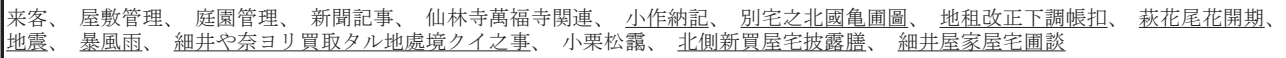 \\
\hline 『明治年中雜録 肆』 & 明治19年 & 60 & 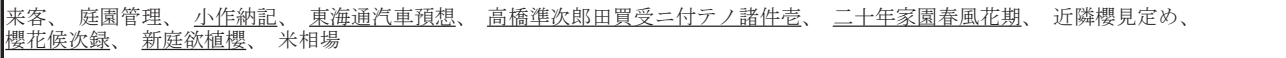 \\
\hline 『明治年中雜録 伍』 & $\begin{array}{l}\text { 明治21年1月24日 } \\
\sim 22 \text { 年1月25日 }\end{array}$ & 60 & 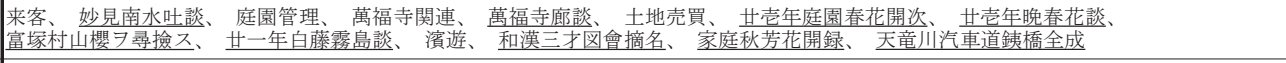 \\
\hline 『明治年中雜録 陸』 & $\begin{array}{l}\text { 明治22年2月1日 } \\
\sim 22 \text { 年12月31日 }\end{array}$ & 57 & 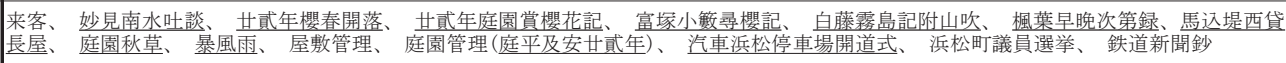 \\
\hline 『明治年中雜録 漆』 & $\begin{array}{l}\text { 明治23年1月 } \\
\sim 24 \text { 年7月29日 }\end{array}$ & 60 & 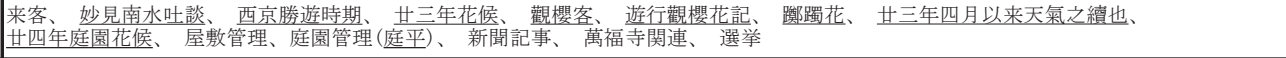 \\
\hline 『明治年中雜録 別』 & 明治24年7月31日 & 57 & 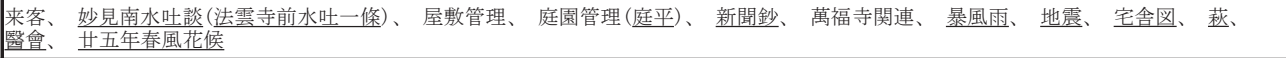 \\
\hline 『明治年中雜録 玖』 & 明治25年12月10日 & 60 & 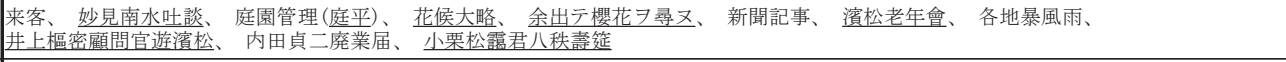 \\
\hline 『明治年中雜録 拾』 & 明治26年10月 & 59 & 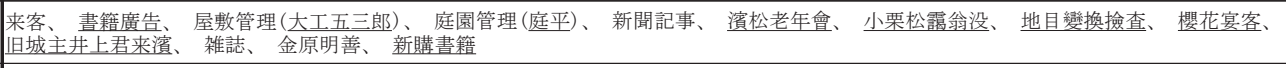 \\
\hline 『明治年中雜録 拾壹』 & $\begin{array}{l}\text { 明治27年5月 } \\
\sim 28 \text { 年10月31日 }\end{array}$ & 59 & 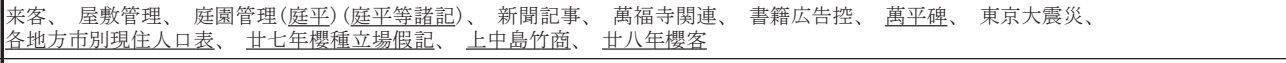 \\
\hline 『明治年中雜録 拾武』 & 明治28年11月1日 & 60 & 来客、屋敷管理(庭平等及諸匠土木類)、庭園管理(庭平等及諸匠土木類)、雜類、新聞鈔、周平旭等記、家人親戚門生奴婢、櫻客 \\
\hline 『明治年中雜録 拾参』 & 欠失 & & \\
\hline 『明治年中雜録 拾肆』 & 明治31年1月 & 60 & $\begin{array}{l}\text { 来客、屋敷管理(庭平及土木諸工)、庭園管理(庭平及土木諸工)、新聞鈔、周平旭等記、家人親戚門生奴婢、雜録、 } \\
\text { 中亭、北郎畐士下風害 }\end{array}$ \\
\hline
\end{tabular}

補注：「主な内容」欄の作成にあたり、原文の見出しを引用したものについては下線を付して区別した。年月日は、表紙に記載された日付を記した。 
ついては、以下の共通点に基づいて推測することができる。『静岡県 明治銅版画風景集』に掲載された個人邸宅の銅版画の中で、「静岡縣 遠江國長上郡 小野田村大字内野廿四番地 農 横田定吉邸宅」に は、「明治廿四年七月十五日家宅ノ真景习模易シテ」とした説明書き がある。これは原文(1) と同時期の明治 24 年 7 月 15 日に調查が行わ れたことを示しており、この事例から類推して、原文(1)、図 2 の 内田正邸の銅版画制作のための屋敷調查である可能性が指摘される。

\section{2 屋敷地の規模の推定}

銅版画から分かる屋敷構えの特徵は、敷地の形状は南北に長く、 東海道に面した正方形に近い北敷地と、奥の細長い南敷地の 2 つの 区画から構成される。次に、北敷地の規模について『明治年中雜録』 の原文及び宅地図から関連する部分を抜粋して推定を行う。

(2)『明治年中雜録 武』(明治 16 年 8 月 18 日の原文・図を拔粋) 我家宅地之事

明治十六年八月十八日余長澤氏二於テ戸長役場ノ新町宅地記ヨ視ルニ 我家ノ宅地八右ノ如シ 南 (図 3 に示す)

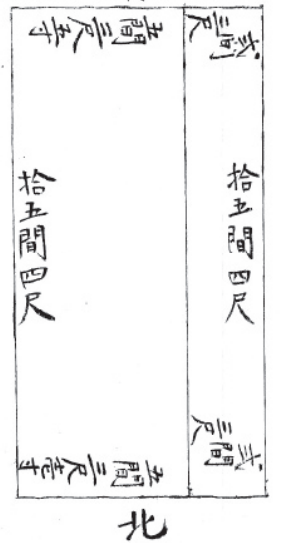

図 3『明治年中杂録 武』新町宅地記による宅地図

(3)『明治年中雜録 参』(明治 18 年 11 月 17 日の原文より抜粋) 細井屋家屋宅戋談

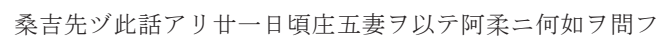

(4)『明治年中雜録 参』(明治 19 年 1 月の原文より抜粋) 長澤宽次郎氏所蔵, 遠江國敷知郡新町 地租改正下調帳 扣原本縦長 ヨ借リ我家ニ於テ要用ナル 部 鈔鴌スル左ノ如シ 七十六翁 内田貞二識

(以下主要部分を図 4 に示寸)

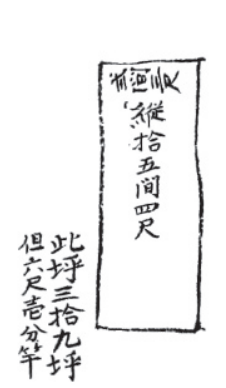

(5)『明治年中雜録 参』(明治 19 年 1 月 20 日の原文より拔粋) 細井や奈ヨリ買取リタル地處境クイ之事

十九年一月二十日貞翁桑吉立具寅三人立會ニテ境クイヨ打ツ寅畑モ地券 面三畧九歩ノ由寅畑境クイ八彼ノ境内ニ打ツ三処我畑境クイ八境内二打 ツ四処也我卜寅卜両家境クイノ間式尺壱寸幅ニテ長式拾間高橋忠平買取 八路地其坪七坪其地券面モ七歩也細井や奈新町宅地南境二境クイ 武本打ツ是レモ彼宅境内ニ打ツ其壱本東ニ在ル者八前ニ説ク寅境クイノ 三処ノ壱ニテ細井南境ノ目当トナル者也(以下略)

(6)『明治年中雜録 拾』(明治 27 年 3 月 31 日の原文より拢粋) 地目戀換檢查 (廿七年)

隠居建築前買込タル舊私路地武尺壱寸幅武拾間長二テ地坪七歩ナル内或 歩八固ヨリ市街宅地其餘南五歩八畑地ノ分ナルラ隠居建築二付其五歩 西郡村宅地壱筆卜合併シ五歩/ 畑地地目 7 變換シ郡村宅地卜為スコト 其節届出シ置キタルニ付 (以下略)

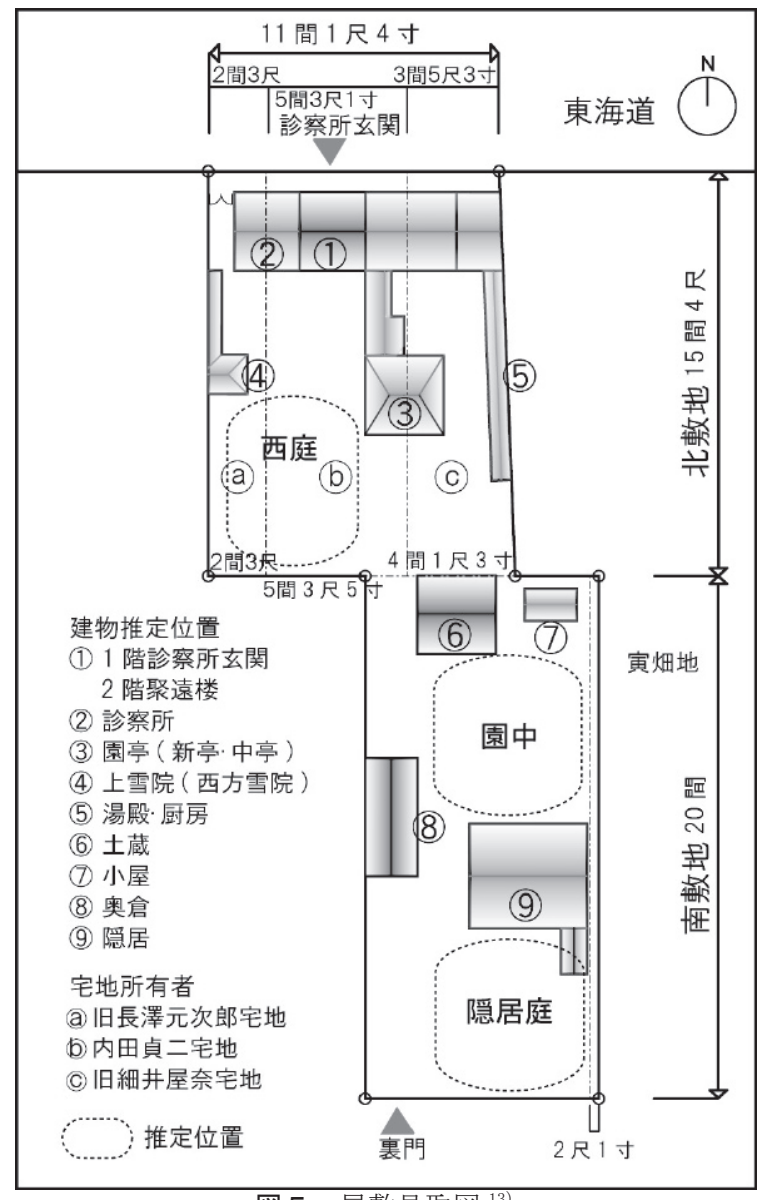

図 5 屋敷見取図

改地百地百地百
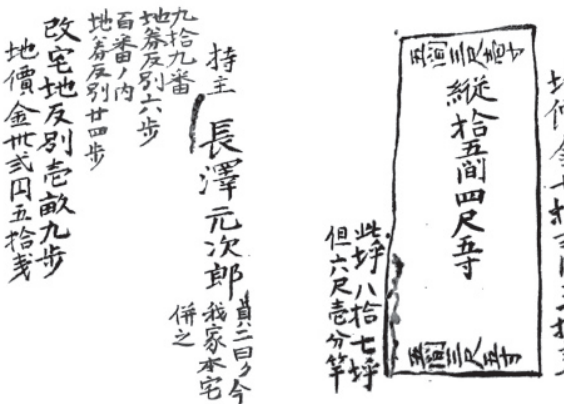

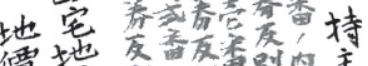

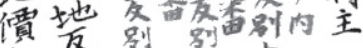
金别壳意步肉 始站放步

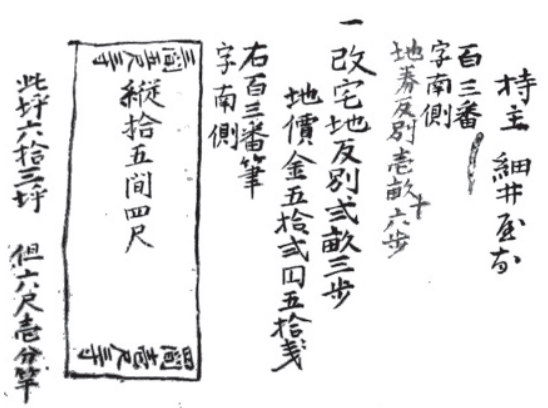

図 4 『明治年中雜録 参』地租改正下調帳写の一部抜粋 ${ }^{12)}$ 
これらの原文と図について、以下に対応関係を述べる。図 3 の宅 地図は、原文(2)の説明図であり、明治 16 年 8 月当時の内田家の宅地 の規模を示す。後年の明治 19 年 1 月に書かれた図 4 の地租改正下調 帳写には、細井屋奈、内田貞二、長澤元次郎所有の 3 つの宅地が並 び示されるが、長澤宅地の追記にある「貞ニ日ク今我家本宅併之」 の内容は、図 3 の宅地図が図 4 に示した長澤元次郎宅地と内田貞二 宅地を併せた規模であることと一致している。さらに、(3)の原文に ある明治 18 年 11 月の細井屋奈宅地の購入話と、明治 19 年 1 月の (5) の原文「細井や奈ヨリ買取リタル地處」から、図 4 に示された 3 つの 宅地は、明治 19 年 1 月 20 日までに、全て内田家の所有となった。 これにより、明治 19 年 1 月時点の北敷地の規模は、図 5 に示すよう に東海道側間口 11 間 1 尺 4 寸、奥行 15 間 4 尺と推測される。

一方の南敷地に関しては、地租改正の写しが無く、詳細な敷地寸 法を確認することができない。そのため、原文(5)と (6)に共通して書 かれた、幅 2 尺 1 寸長さ 20 間」の土地の地目変換の経緯から敷地寸 法を推測する。原文(5)の下線部の記録から、高橋忠平から貞二が購 入した路地が、寅の畑地と貞二の畑地の間にあり、幅 2 尺 1 寸長さ 20 間であったことが示されている。原文(6)では、この路地が「隠居 建築前買込タル舊私路地」とされ、その路地の南部分 5 歩を「隠居」 建築の施工時に、西の郡村宅地と一筆とし宅地に地目変換したと記 されている。銅版画に描かれた南敷地の東塀に沿った建物を「隠居」
建築と想定すると、(5)「我畑」とは南敷地を指すものと考えられ、 南敷地の奥行きは 20 間と推測される。以上の屋敷地の成立時期につ いて再整理すると、屋敷地の成立は明治 19 年 1 月頃で、その後、画 工の調查が行なわれた明冶 24 年 8 月までに、銅版画に見られるよう な屋敷の様子にするための建築や庭園の整備が行われた。

\section{4. 屋敷及び庭園の作事について}

『明治年中雜録』に記載された屋敷及び庭園の作事について、年 表を整理したものが、[表 2 ]（屋敷及び造園工事年表 明治 14 年〜 明治 24 年) と［表 3 ］（屋敷及び造園工事年表 明治 25 年〜明治 31 年)である。屋敷工事の項目は、北敷地と南敷地に区別して表を作成 し、建物毎に工事の経緯を示した。また造園工事については、工事 の項目を「施工」「維持管理」「調達」の大項目で区別し、大項目を さらに作業種毎の小区分に分類して、日付と作業の内容を原文から 抜粋して年代順に表を作成し、工事の経緯を示した。屋敷地には、 図 5 に示寸ように、北敷地内にある「西庭」、南敷地内の「隠居庭」 「園中」の計 3 箇所に庭園が存在したことが、図 2 の銅版画からも 確認されるが、原文から施工位置が明らかなものについては、表に 記載した【月日】の冒頭に、それぞれ別の記号（○一西庭 $\triangle$ 一園 中（－隠居庭）を付記し、施工位置を区別した。

明治 16 年 2 月に内田貞二の長男の正が宅地を相続し ${ }^{14)}$ 、それに

表 2 屋敷及び造園工事年表 明治 14 年〜明治 24 年

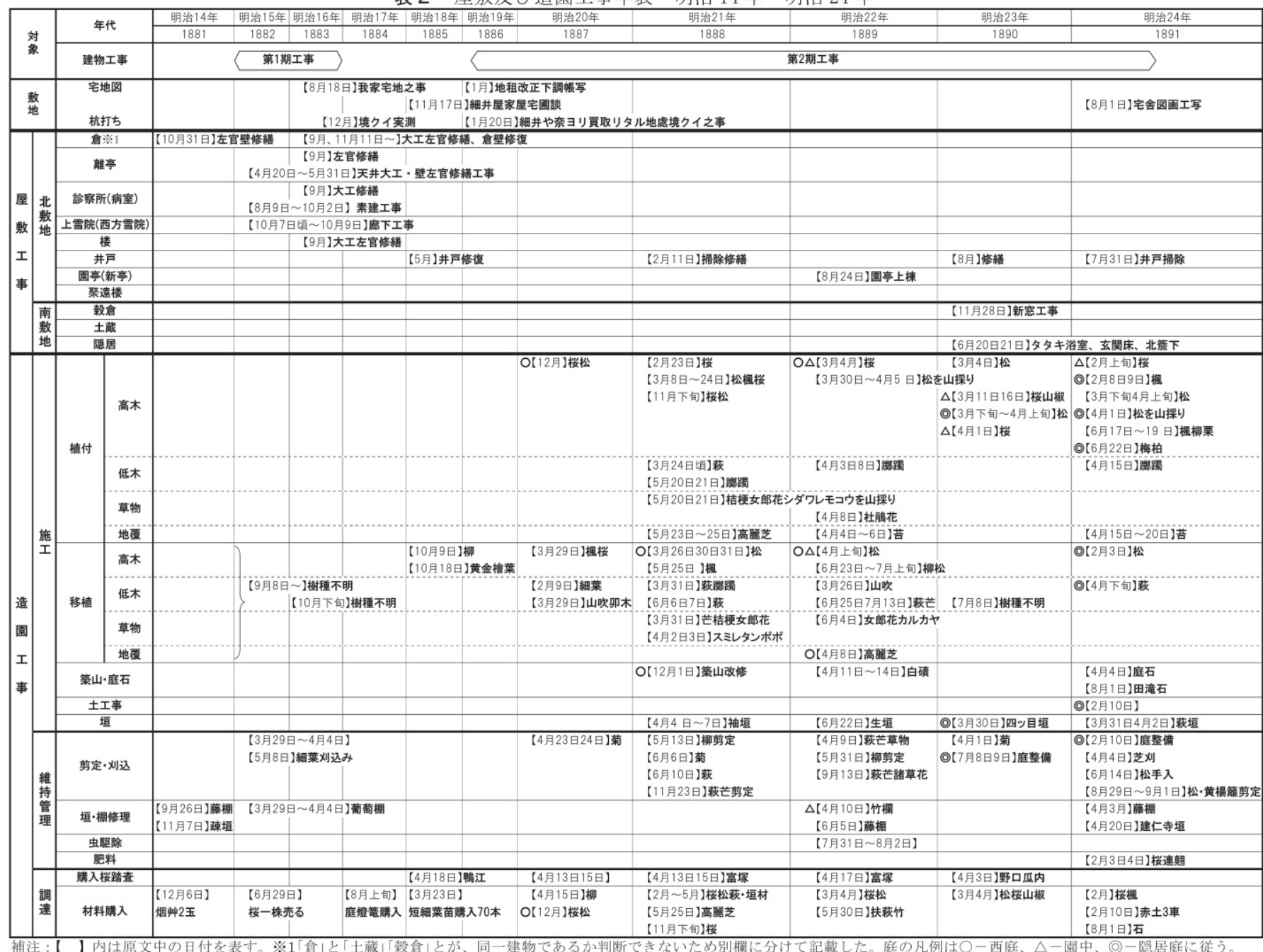


ともなう屋敷地の拡張と、屋敷の新築や修繥のための工事が始まっ た。なお、建築工事については長男正が主体的に行ない、貞二は軽 微な修繕工事と庭園を主に担当していたものと考えられる ${ }^{15)}$ この 作事の全体の流れを大別すると、明治 15 年から明治 16 年に行なわ れた、建物全般に及ぶ軽微な修繥と、「診察所」の素建を主とした〔第 1 期工事了。そして、明治 19 年から明治 24 年の、「園亭」や「隠居」 新築により、銅版画に描かれた屋敷形態となる〔第 2 期工事〕そし て、それ以降に行なわれた「園亭 (中亭)」の増築や「土蔵」の修復、「上 雪院 (西方雪院)」「聚遠楼」の屋根莫替といった〔第 3 期工事〕の、3 期にわたり建築工事が行われている。

一方、造園工事については、明治 14 年から明治 18 年にかけては、 庭園の日常的な手入から、軽微な移植を主としたものであった。ま た、明治 20 年 12 月から「園亭」近くの「西庭」の造園工事が始まり、 これは明治 22 年 8 月の園亭上棟に先駆けて行われている。明治 21 年 12 月に「西庭」の築山改修、明治 22 年 3 月頃からは「園中」付 近の造園にも着手し、明治 22 年 6 月にかけて、桜樹や松など高木の 植栽が行われている。さらに、明治 23 年 3 月頃から「隠居庭」の本 格的な造園工事がはじまり、明治 24 年の 2 月から春先にかけて、高 木の植付けや移植が行われ、銅版画に見られるような植栽を主とし た庭園の骨格がほぼ完成した。次に、第 1 期から第 3 期までのそれ ぞれの工期について、建物の起工と造園工事の相互関連を分析する。

\section{1 第 1 期工事について}

第 1 期工事は、明治 14 年 10 月 31 日 の左官定による「倉」壁の修 繕から始まり ${ }^{16)}$ 、明治 15 年 4 月 20 日の大工桑吉による「離亭」の天 井板張替え ${ }^{17)}$ および、左官定による壁の補修が行なわれている ${ }^{18)}$ 。 更に同年の 8 月 9 日から 10 月 9 日まで、「診察所」および「上雪院」 の工事が行なわれており、その記録を［表４］（「診察所素建て」「上 雪院廊下」工事に関する原文の抜粋) に整理した。人工数、大工との 遣り取りまでを詳しく記録した、大工、左官、屋根莫職人の工賃の 覚書と捉えられるが、この中で明治 15 年 8 月から行われた「診察所」 の素建の位置については、細井屋奈宅地側の敷地拡張以前であるた め、図 5 の北敷地内に示した (a) (b)区域にあったと考えられ、工 事は、大工桑吉が施工し、9 月末日に請負分として、56 円 75 銭が支 払われている。なお、10月 2 日の「桑吉又云ク診察所素立雑作共惣 成百五拾壱工心算也卜」から、「診察所」素建等の工事規模は、総数 151 人工にも及んだことが読み取れる。また、9月19日と 21 日に「定」 「信」「勘」の 3 人の左官職人が従事したこと、屋根草工事には、9 月 20 日に勝組が施工したことなどが記載されており、その後、引き続 き 10 月 7 日より「上雪院」の廊下工事が行なわれている。翌 16 年の 9 月には、「倉」離亭」「診察所」楼」といった建築物全般にわたり、 開き戸の下削や立て付けの直し、湯殿のタタキ補修など大工と左官 ${ }^{19)}$ による軽微な補修工事が行なわれ、その後の同年 11 月 11 日から

表 3 屋敷及び造園工事年表 明治 25 年〜明治 31 年

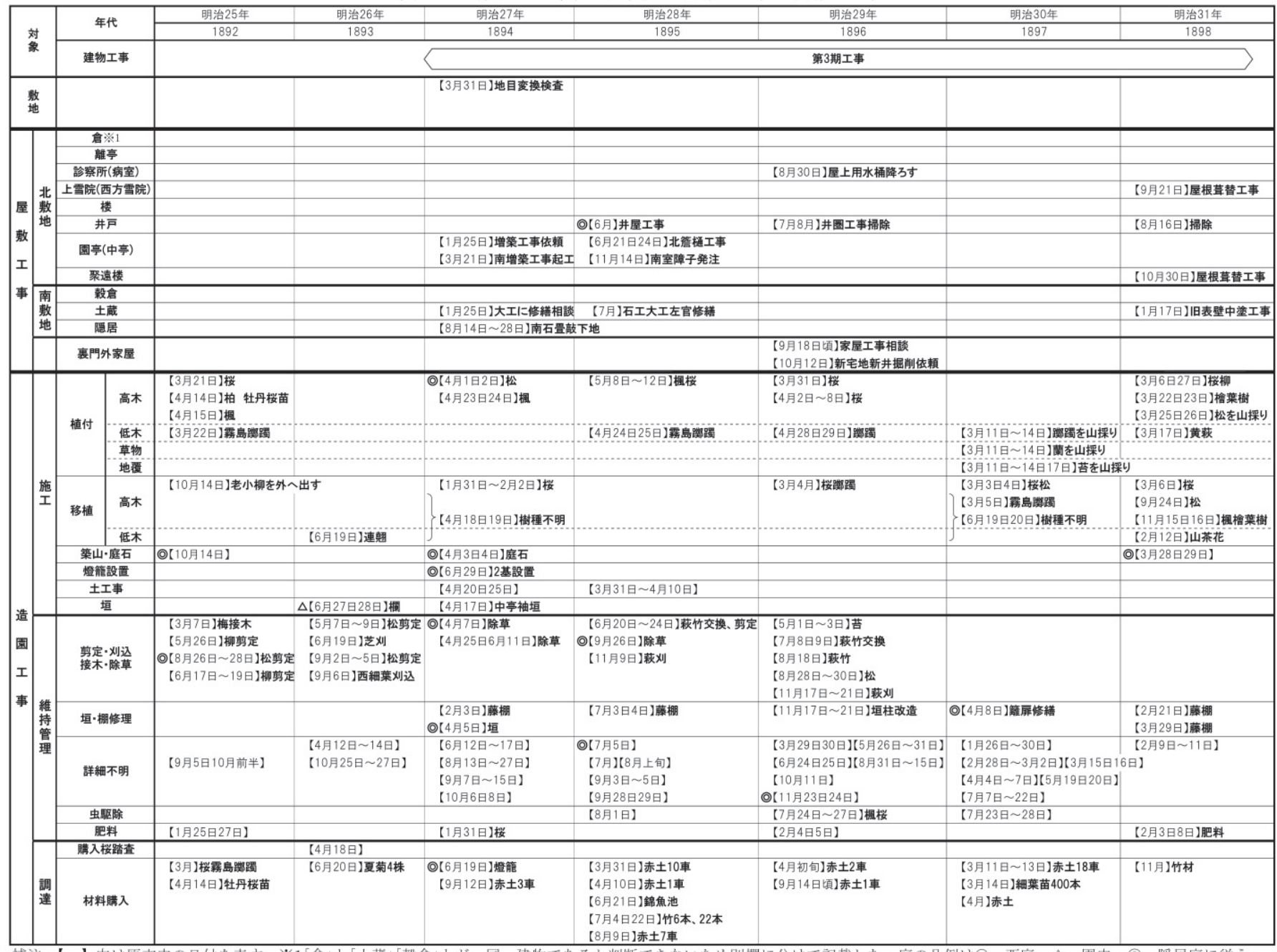

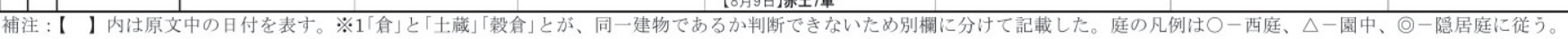


表 4 「診察所素建て」「上雪院廊下」工事に関する原文の抜粋

\begin{tabular}{|c|c|}
\hline 日付 & 明治15年(1882) \\
\hline 8月9日 & 桑吉及常 八月九日ヨリ \\
\hline 9月19日 & 左官九月十九日定信両人雨二テ早仕舞 \\
\hline 9月20日 & 屋根勝等九月廿日頃老匠一人来板ヨモミ \\
\hline 9月21日 & $\begin{array}{l}\text { (左官)廿一日甚定信三人早仕舞 } \\
\end{array}$ \\
\hline 9月22日 & (屋根勝)九月廿二日三人来り菩ク \\
\hline 9月29日 & 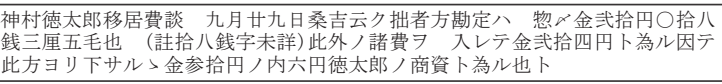 \\
\hline 日付な & 桑吉受負分西補診察所＼cjkstart素立豫約工手間食料共＼cjkstart蓋金五拾六円七拾五銭也 \\
\hline 9月々末 & 桑吉勘定之事 九月々末 金五拾六円七拾五銓 診察所受負分ᄏ皆渡シトナル \\
\hline 10月2日 & 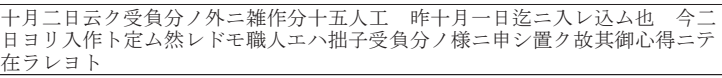 \\
\hline & 桑吉又云ク診察所素立雑作共牢成百五拾壱工心算也卜 \\
\hline & 上雪院廊下 十月七日頃ヨリ九日ニ至ル \\
\hline
\end{tabular}

表 5 明治 20 年· 21 年の造園工事の抜粋

\begin{tabular}{|c|c|}
\hline 日付 & 明治20年(1887) \\
\hline 2月9日 & 大細葉中細葉移植 二十年二月九日平兵衛及ビ弟子来リ千松助手ニテ移ス \\
\hline 3月29日 & 三月廿九日庭平来移西庭大小楓山櫻及米櫻山吹卯木植于外園 \\
\hline 4月 & 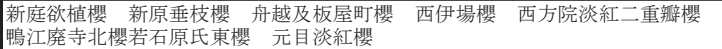 \\
\hline 4月13日 & 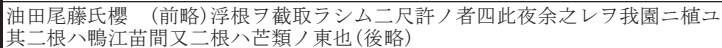 \\
\hline 4月15日 & 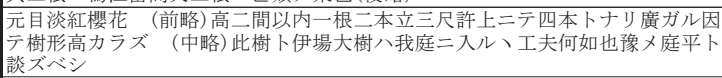 \\
\hline 4月23日 & エゾ菊薪子秋菊整頓廿年四月廿三日廿四日庭平略壱人半工 \\
\hline 12月2日 & 十二月二日頃ヨリ庭平来 \\
\hline 12月7日 & 移 元目櫻價七拾銭 幸内櫻䜖五拾銭 先ヅ南屏九日頃 \\
\hline 12月8日 & 移 池川松二本謝ヨシカモ雌雄合目田毛 是九日植込 \\
\hline 12月11日 & 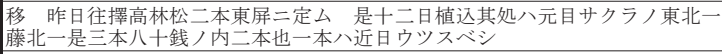 \\
\hline 12月13日 & 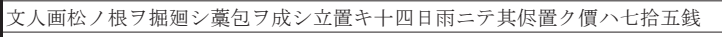 \\
\hline 12月15日 & 大松ノ根ヨ掘廻シ葍包シ置キ南屏松卜文人画松トヨ移シ \\
\hline 12月16日 & 鈛 \\
\hline 12月17日 & 文人画松大松南坔松三本 7 植込ミ定ム \\
\hline 日付 & 明治21年(1888) \\
\hline 2月26日 & 建仁寺坦材七寸上竹拾五本中島村平吉ヨリ買フ價八拾七銭五厘 \\
\hline 2月23日 & 野口村平三郎山櫻價拾五銭 二月廿三日頃移来 \\
\hline 3月8日 & 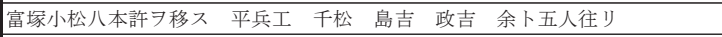 \\
\hline 3月11日 & 植平＼cjkstart政吉＼cjkstart去年買置ノ高林小三岐松ヨ移ススイツバ数多 \\
\hline 3月12日 & 古楓ヨ畑ヨリ園二移ス \\
\hline 3月24日 & $\begin{array}{l}\text { 鴨江村喜太郎ヨリ櫻ヨ移ス是レ喜太郎ノ惠ム所ノ者也 } \\
\text { 部氏ヨリ皎移 }\end{array}$ \\
\hline 3月26日 & 倉後ノ雄松＼cjkstart唇巳㧑篗内二移ス \\
\hline 3月30日 & 高松枯者二本ク除ク＼cjkstart突當屏前松ヨ西山二移ス \\
\hline 3月31日 & 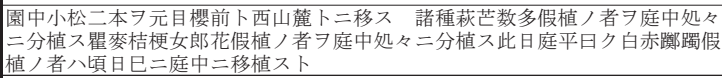 \\
\hline 4月1日 & 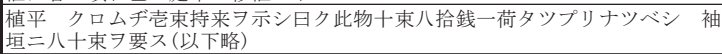 \\
\hline 4月1日 & 黑淡黒微黒ノ三柳等ヨロヂ外二移ス \\
\hline 4月2日 & 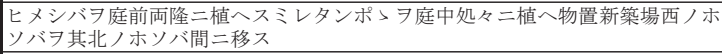 \\
\hline 4月3日 & 園ミゾロノ諸茾ア移ス \\
\hline 4月4日 & 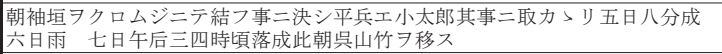 \\
\hline 4月13日 & 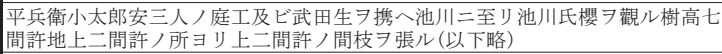 \\
\hline 4月15日 & 平兵衛ᄏ引キ好櫻 索ム(以下略) \\
\hline 5月13日 & 亭前柳條ヨスカス略半分ナルベシ \\
\hline 5月20日 & 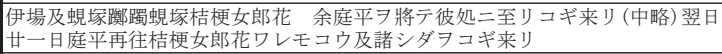 \\
\hline 5月23日 & 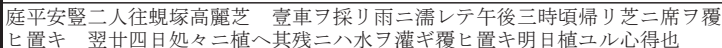 \\
\hline 5月25日 & 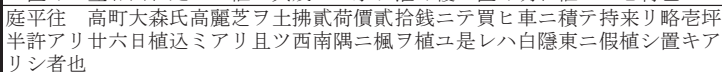 \\
\hline 6月6日 & 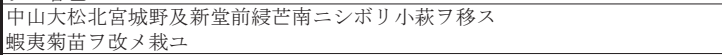 \\
\hline 6月7日 & 仍他処二小萩ヨ移ス庭平曰ク裏門外竹欄内二在儿萩八大抵中立白萩也 \\
\hline 6月10日 & 高山北腹ノ萩ヨ中断ス蓋シ絞萩也 \\
\hline 11月23日 & 萩芒ヨ刈ル \\
\hline 11月24日 & 富塚大櫻 コギ子カシサ五日移シ来ル樹價金七拾銭 (以下略) \\
\hline 11月26日 & 澤村雪白絮毬櫻樹價三拾五銭＼cjkstart午后庭平等四人往移来 \\
\hline 11月27日 & 小繁村山櫻樹價五拾五銭＼cjkstart早朝庭平師弟及名残三人往キ夕移来植 \\
\hline 11月28日 & 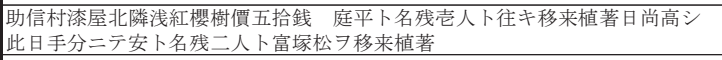 \\
\hline 11月29日 & 庭平庭安名残一人ニテ庭中櫻松数株ノ位置ヨ改ム午后千松来少助ク \\
\hline 12月1日 & 假山庭平庭安名残一夫改山容加風致 動洞壇大小二樹移作左近傍小松植于大 \\
\hline
\end{tabular}

表 6 明治 22 年の造園工事の抜粋

\begin{tabular}{|c|c|}
\hline 日付 & 明治22年(1889) \\
\hline 3月25日 & 溝東松 ヨ西屏畔二移シ其跡へ大舟越櫻 引引ク \\
\hline 3月26日 & 蝦夷菊實 蕂キ山吹习溝東ニ移ス \\
\hline 3月27日 & 本郷櫻 園中小屋北二移又樹價三拾銭 \\
\hline 3月28日 & 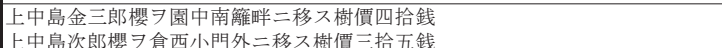 \\
\hline 3月29日 & 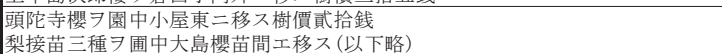 \\
\hline 3月30日 & 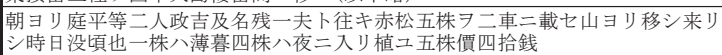 \\
\hline 3月31日 & 朝ヨリ庭平等二人及名残二人往キ赤松大二株小二ヨ二車二載セ山ヨリ移シ来り \\
\hline 4月1日 & 昨ノ四松ヨ植へ畢リタル八略午后二時ナルベシ雨来リ四人其家二帰ル \\
\hline 4月2日 & 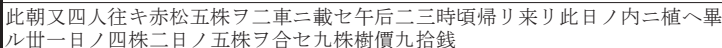 \\
\hline 4月3日 & 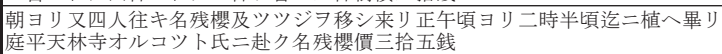 \\
\hline 4月4日 & 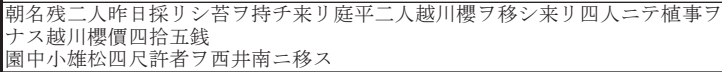 \\
\hline 4月5日 & 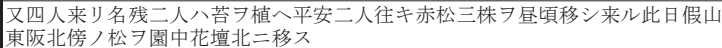 \\
\hline 4月6日 & 又四人苔习植ユ午后五時雨来夜亦雨 \\
\hline 4月8日 & 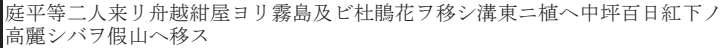 \\
\hline 4月9日 & 平安二人支竹 ヨ減ジ藤枝ヨ下グ萩芒ヨ整頓シカキッバタアヤメ等ヨ整頓ス \\
\hline 4月10日 & 平安二人来リ園中竹欄习換へ新シクシ等ヨナシ成功ヨ告ゲ切リ揚ゲトス \\
\hline 4月11日 & 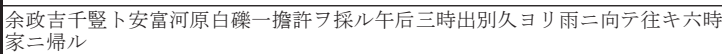 \\
\hline 4月12日 & 午后一時十分頃ヨリ庭平来リ山間水路へ白磧ヨ敷ク \\
\hline 4月14日 & 朝政吉千豎ヨ遣リ更二安富石ヨ採リ政吉ヨシテ前石上ニ敷カシム \\
\hline 4月17日 & 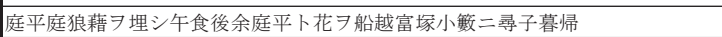 \\
\hline 5月8日 & 両人来リ午前雑事午后雄松ヨ山ヨリ別宅二移ス \\
\hline 5月10日 & 午后庭平蓮移萩竿等 \\
\hline 5月31日 & 両人来平兵エハ柳條ヨスカス \\
\hline 6月4日 & 平兵女郎花及カルカカヤ移シ五日藤棚添千松竹 \\
\hline 6月19日 & 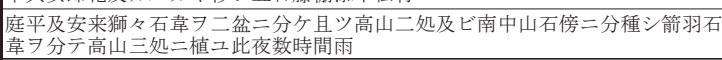 \\
\hline 6月20日 & 平安二人来エゾ菊(以下略) \\
\hline 6月21日 & 平安二人来リ大島櫻苗及ビ諸根分櫻苗 \\
\hline 6月22日 & 二人来リ細葉長苗ヨ移シ生垣トス \\
\hline 6月23日 & 平安二人来諸植換 \\
\hline 6月25日 & 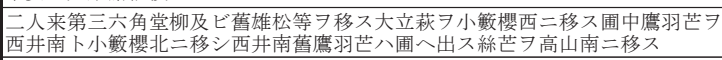 \\
\hline 6月26日 & 安一人来 \\
\hline 7月6日7日 & 平兵一人来 \\
\hline 7月13日 & 午后二三時頃ヨリ平安名残来リ萩ヨ移シ萩ヨ扶クル等ヨナス \\
\hline 7月17日 & 又平兵来ル款 \\
\hline 7月25日 & 午后四五時頃ヨリ平兵一人来ル \\
\hline 7月31日 & 三日間平安二人来リ蟲除キ松スグリ橙モクコク剪入萩スカシ等ヨナス \\
\hline 8月25日 & 又平一人来リ萩ヨ理ス \\
\hline 9月13日 & 平安及ビ名残一人来リ大櫻大柳ノ半臥ヨ起シ萩芒諸草花 シ 刈リ清入(以下略) \\
\hline 10月3日 & 平兵衛来 \\
\hline
\end{tabular}

表 7 「隠居庭」の造園工事の抜粋

\begin{tabular}{|c|c|}
\hline 旦付 & 明治23年(1890) \\
\hline 3月25日 & 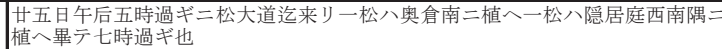 \\
\hline 3月26日 & 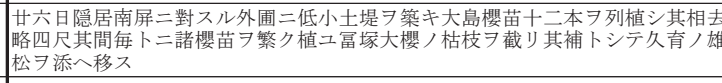 \\
\hline 3月30日 & 三十日木戸山椒ヨ移シ隠居北室外ノ四ツ目䉏Э結ブ \\
\hline 4月7日 & 七日正午隠居中庭二植へアリ午后伊場へ往キ又赤雄二松ヨ持チ来リ同庭二植二 \\
\hline 7月8日 & 七月八日平安二人来リ中坪新植隠居庭少整頓畑樹ヨ内ニ入ル等 \\
\hline 日付 & 明治24年(1891) \\
\hline 2月3日 & 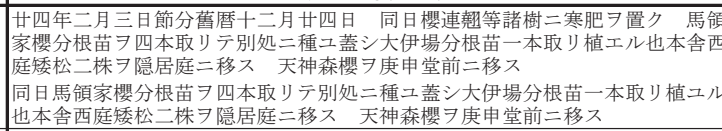 \\
\hline 2月8日 & 平安政三人ニテ楓ヨ舟越幸内ヨリ移シ隠居庭ニ植ユ \\
\hline 2月9日 & 舊暦正月元日也庭平安及政名残楓 \\
\hline 2月10日 & 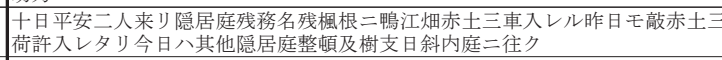 \\
\hline 4月1日 & $\begin{array}{l}\text { 四月一日大安卜名残来り政吉ト三人シテ植へ込么 競馬山ヨリ松一株ヨ移シ来リ隠居庭 } \\
\end{array}$ \\
\hline 4月17日 & 松习隠居庭二移ス \\
\hline 6月22日 & 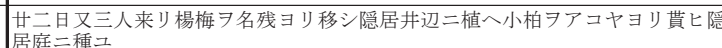 \\
\hline
\end{tabular}


は左官定により「倉」壁の修復工事が行なわれていた ${ }^{20)}$ 。

以上により、明治 15 年の 8 月から 10 月にかけた 2 ケ月間の工事 は、「診察所」の素建工事で、翌 16 年 9 月の補修工事は、屋敷全体の 軽微な補修工事であったと考えられる。

\section{2 第 2 期工事について}

第 2 期工事 (明治 19 年から明治 24 年まで) は、東海道沿いの建物 棟の増築、および「園亭」と「隠居」の新築など、銅版画に描かれた屋 敷形態に導く一連の工事である。しかし『明治年中雜録』には、屋 敷工事に関する記録は少なく、屋敷の成立過程は定かではない。一 方、庭園については、樹木の植栽位置から材料の搬入期までが詳細 に記録されており、これに基づいて、屋敷地内の何処を対象に造園 工事が行われたかを推定することが可能である。明治 20 年から 21 年にわたる築庭の内容を整理したものが [表 5 ] (明治 $20 ・ 21$ 年の造 園工事の抜粋) である。主な内容は、明治 20 年 4 月の新庭の桜の選 定から始まり、同年の 12 月 7 日に「元目桜」 $\rfloor^{211}$ 等の植栽位置を「先ズ 南塀」と定めているが、銅版画の細部に着目寸ると、南敷地の南塀側 には桜が描写されていないため、「元目桜」は北敷地の「西庭」の南塀 付近に植えられたと推測される。また、松については銅版画でも各 所に植樹されている様子が表現されているが、植樹の様子は、大松 を 13 人で運搬するなど大掛かりなものであった。次に明治 21 年の 築庭の内容については、2 月下旬から 4 月初旬までは、桜や楓、松 の植樹から、庭園の各所にある松を「西庭」に移植するなどの作業に 加え、仮植えであった植物を庭の所々に分け植えるものであった。 同年の 11 月 24 日には、近隣の桜 1 本を新たに 70 銭で購入し、 11 月 26 日から 28 日には 3 本の桜を総額 1 円 40 銭で購入し、14 人工 の庭師により邸内に運び込み植樹されている。その後、12月 1 日に 「仮山 ${ }^{22)}$ の山容の改めが、庭師 3 人工により行なわれている。これ ら 21 年の築庭内容は、主に「西庭」付近の整備であったと推測される。

明治 22 年の築庭の内容を整理したものが [表 6 ] (明治 22 年の造園 工事の抜粋)である。これによれば、3 月から 6 月にかけて、64 人工 の庭師が造園に従事しており、3 月末には「溝東」23)に桜や山吹を移植 し、また、新たに購入した桜 4 本を「園中」や「倉 (土蔵)」 $\rfloor^{24)}$ の西小門近 くに植え、赤松 17 本を園内に運び寄せ植樹している。さらに、4月 9 日には、萩、芒など草花の手入を行い、翌 10 日には、「園中」の竹垣 を組み、12 日には山間に白石を敷き詰めるなど、造園工事の仕上げ段 階の様子が窥える。これら一連の「溝東」や「園中」「西山（西庭）」の工 事は、8月 24 日の「園亭」の上棟式に先駆けた工事であり、この時点に おいて庭園の骨格がほぼ完成したものと思われる。なお、翌年の明治 23 年 3 月 16 日に、新亭 (園亭)の北庭に桜が植樹され、「園亭」付近の 造園に着手している様子と ${ }^{25)}$ 、明治 23 年の 3 月 29 日から 4 月 1 日に 集中して桜見客が 80 人近く来訪した記録から ${ }^{26)}$ 、「園亭」は、この時 期までに完工していたものと推測される。

次に、敷地の最奥地にある「隠居庭」の工事内容について整理したも のが [表 7 ] ( 隠居庭」の造園工事の抜粋)である。「隠居庭」の最初の造 園工事は、明治 23 年 3 月 25 日、西南隅の松の植樹であった。その後、 赤松などを植え、明治 24 年 6 頃までに整備された様子が窥える。な お、明治 23 年 3 月 30 日に「隠居」北室外の四ツ目垣が結ばれるなど、 外構に着手している点と、6月 $20 、 21$ 日の 2 日間にわたり浴室や玄関 等のタタキ工事 ${ }^{27)}$ が行なわれている点から、「隠居」と呼ばれる建物は 明治 23 年 7 月頃に竣工したと推定される ${ }^{28)}$ 。

\section{3 第3 期工事について}

第 3 期工事は、明治 27 年 1 月 25 日の、正が大工五三郎に「中亭(園 亭）」の拡張工事を依頼することに始まり ${ }^{29)}$ 、同年の 3 月 21 日に起 工されている ${ }^{30)}$ 。また、翌年 28 年の 11 月 14 日には建具寅に、南 室の 2 間半 4 本引きの障子を注文している ${ }^{31}$ 。

翌年 28 年 7 月には、「土蔵」の工事が行われた ${ }^{32)}$ 。土蔵工事の人 工を[表 8］(土蔵修繥工事 人工表)に整理したように、 伊豆石 33 本が搬入され、大 工が 7 人工、左官が 13 人工、 石工が 6.5 人工、黒鍬が 4 人工従事する修復工事が行 なわれている。その後、明 治 31 年 1 月 17 日に左官定 は、「土蔵」の旧表壁を削り 中塗りに従事しており ${ }^{33)}$ 、 老朽化により度重なる補修

表 8 土蔵修繒工事人工表

\begin{tabular}{|c|c|c|c|c|c|}
\hline 日付 & \multicolumn{4}{|c|}{ 大工左官:石工黒鍬 } & 材料 \\
\hline 7月3日 & 2 & & & & \\
\hline 7月4日 & 1 & 3 & 1 & & \\
\hline 7月5日 & & 1 & & & \\
\hline 7月6日 & & 2 & & & 伊豆石22本 \\
\hline 7月7日 & & 1 & & & \\
\hline 7月8日 & & 1 & 1 & & \\
\hline 7 月9日 & 1 & & 1.5 & 2 & 伊豆石11本 \\
\hline 7月10日 & 1 & 1 & 3 & 2 & \\
\hline 7月11日 & 2 & 2 & & & \\
\hline 7月12日 & & 1 & & & \\
\hline 7月13日 & & & & & \\
\hline 7月14日 & & 1 & & & \\
\hline 合計(人工) & 7 & 13 & 6.5 & 4 & 伊豆石33本 \\
\hline
\end{tabular}
工事がなされたものと考えられる。

また、勝組による亜鉛引鉄板を用いた「西方雪院(上雪院)」および 「聚遠楼」の屋根莫替工事が、同年の 9 月、10 月に起工されたが ${ }^{34)}$ 、 銅版画の細部に照合すると、図 6 に掲載した門長屋の拡大図から、 門長屋と、その背後の西塀沿いの建物の屋根仕上げが同一であるこ とより、西塀沿いに建築された、廊下を有する小規模な建物が「上雪 院」で、「聚遠楼」は、門長屋の中央にある二階部分と考えられる。「聚 遠楼」の名称は明治 24 年の記録に確認されるが 35 )、当時の建物の使 用の様子が、明治 22 年 4 月 19 日の原文に「微雨モ亦一奇 7 添へ(中 略) 楼上最奇観桑吉賞歏シ曰ク名古屋伊藤ノ名櫻庭に譲ラズ」と、施 主の貞二と大工桑吉の会話記録が残されており、楼すなわち「聚遠 楼」からの桜の眺めを賞賛した内容である。他にも、春の桜の時期に 土地の名士を招いて、花宴が盛大に開かれた様子などが記録されて いる。「聚遠楼」の一階には、式台付の玄関が描かれ、その左右に連 続格子で覆われた診察所建物が見られる。「診察所」については、明 治 15 年 9 月 20 日の原文に「屋根勝等九月廿日頃老匠一人来板 モモミ 九月廿日三人来り葺ク」とあり、「板ヨモミ」の記述から類推して、「聚 遠楼」と同じ带鉛引鉄板で仕上げられ、銅版画からも、門長屋を診察 所とし ${ }^{36)}$ 、その一部を二階建にし眺望良好とした様子がうかがえる。

その他の建物位置については、「隠居」は、前述した敷地の拡張経 緯からも、南敷地の東塀沿いにある建物と推定し、「園亭」(新亭、中 亭) は、北敷地の中央より東側にある、旧細井屋奈宅地側の建物と考

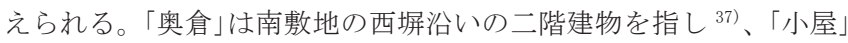
は南敷地の北塀沿いにある狭小な建物、「厨房」38) と「湯殿」は、煙突 が二箇所描かれていることからも、北敷地の東塀に沿った細長い建 物と推定される。北敷地の南西角には、「西庭」と呼ばれる桜や松を 多数植栽した築山があり、北敷地の東寄りにある「園亭」の座敷から 庭園を望む構図となっている。南敷地と北敷地の境には「土蔵」が あり、その両脇の小門から南敷地に誘導され、南敷地の西塀沿いに 倉、東塀沿いには貞二の住居と思われる「隠居」が建設され、その南 側には、「隠居庭」と呼ばれる、松と楓を植え、門と飛び石を配置し た茶庭風の築庭が見られる。さらに、建物北側にある庭は、「園中」 と呼ばれ、桜樹を主体とした作庭手法である。 
以上の一連の工事内容の解明により、屋敷内の建物と庭園の配置 について、図 5 の「屋敷見取図」に示寸内容が結論付けられた。

この他に、明治 29 年 (1896) 9 月 18 日頃、大工五三郎に「裏門外家 屋」の建築の相談を持ち掛けており ${ }^{39)}$ 、さらに、同年 10 月 12 日に は、田圃由組に「裏門外家屋」の井戸の掘削を依頼している ${ }^{40)}$ 。この 内容から、屋敷をさらに拡大寸る計画があったと推察される。

\section{4 関連職人について}

第 1 期から第 2 期までの大工工事には桑吉が従事しており、左官 工事は定、板金工事は勝組が継続して従事している。さらに第 3 期 の大工工事は田町の五三郎が担当し、左官、板金工事に関しては第 1 期 2 期と同じ人物が担当した。桑吉は本名を高橋桑吉といい ${ }^{41)}$ 、 新町に住み、銅版画に見られる屋敷を完成させた人物である。また、 萬福寺の木工事の請負も確認された ${ }^{42)}$ 。さらに、細井屋奈宅地の土 地売買にも関わり、大工職以外の関与もみられた。

庭平 (庭作平兵衛) は、記録に見える庭師名では最も多く確認され、 造園工事の一連の指導指揮を行なった人物である。浜松地方におけ る庭師の系譜については、これまでにほとんじ解明されておらず「庭 平」の名も初出であるが、庭平は地元の医師の福島豊策邸や、茶産 業の施設である「百里園」の造園に携わった経緯が記されている ${ }^{43)}$ 内田家の別宅や野口町の邸宅にも従事し ${ }^{44)}$ 、内田家の造園全般に関 わり、また、貞二と共に樹木の調查に現地に赴くなど、施主の好み を熟知した内田家の専属的な庭師であった。さらに、地元の名士や、 企業からも造園の依頼を請け負うほどの、当地方を代表する庭師で あったことが確認された。

\section{5.まとめ}

以上の『明治年中雜録』の分析によって、内田家の屋敷拡張経緯 と、敷地内の建物および庭園に関する工事の具体的内容が明らかと なった。建物の起工と造園工事には相互に時期的な関連がみられ、 建物群の充実にともない庭園の美観が整えられていった。

屋敷と庭園の成立過程を整理すると、明治 15 年から 16 年の間に 行なわれた〔第 1 期工事〕は、「診察所」の素建や建物全般の軽微な 修䋨であり、樹木の移植も同時期に行なわれた。明治 19 年 1 月の隣 地買収により、『静岡県明治銅版画風景集』の銅版画に見られるよう な敷地形態が成立した。[第 2 期工事〕は、建物の新築工事に先駆け、
明治 20 年 12 月末から「園亭」近くの「西庭」の造園が始まり、明治 22 年 3 月頃からは、「園中」付近の造園にも着手し、明治 22 年 6 月にか けて植栽を主とした庭園の骨格がほぼ完成した。その後、8月に「園 亭」が上棟し、翌年 23 年 3 月に完成し、「隠居」の完成も同年 7 月頃 であったと推測される。「隠居庭」は、明治 23 年の 3 月頃から本格的 に造園工事が始まり、明治 24 年 6 月頃までに銅版画に見られる庭園 形態に至ったと考えられる。以上から、建物の起工及び造園時期の 順序は、北敷地の「西庭」に続き「園中」へと造園工事が進められ、そ の後「園亭」と「隠居」の新築工事が行なわれた。こうした建物と庭園 の相互関連については、樹木の搬入経路の確保を考慮したことが要 因に挙げられ、南敷地の南側から材料を搬入するために考えた建築 順序であったことが推測される。〔第 3 期工事〕は、「土蔵」「上雪院」 「聚遠楼」の補修工事である。よって、これら 3 つの建物は建築年数 が比較的経過していた建物と考えられる。

本研究で取り上げた『静岡県明治銅版画風景集』には、浜松市一 帯の屋敷が多数掲載され、とりわけ既に現存していない家屋や庭園 の様子を知る上で重要な資料である。本研究により、内田家の植栽 の調達は、名残や鴨江、富塚といった浜松城の西地域一帯の内田家 近隣であった点が明らかになったが、こうした特徵は、おそらく浜 松城下町内にある明治期の屋敷庭園全般に共通寸るものと予測され る。当地方の庭園の生産体系については、ひき続き研究を行いたい。

本研究をまとめるにあたり、『明治年中雜録』の所蔵の状況に関し て、浜松市史編纂室の鈴木正之氏より多くの御教示をいただきまし た。厚く御礼申し上げます。

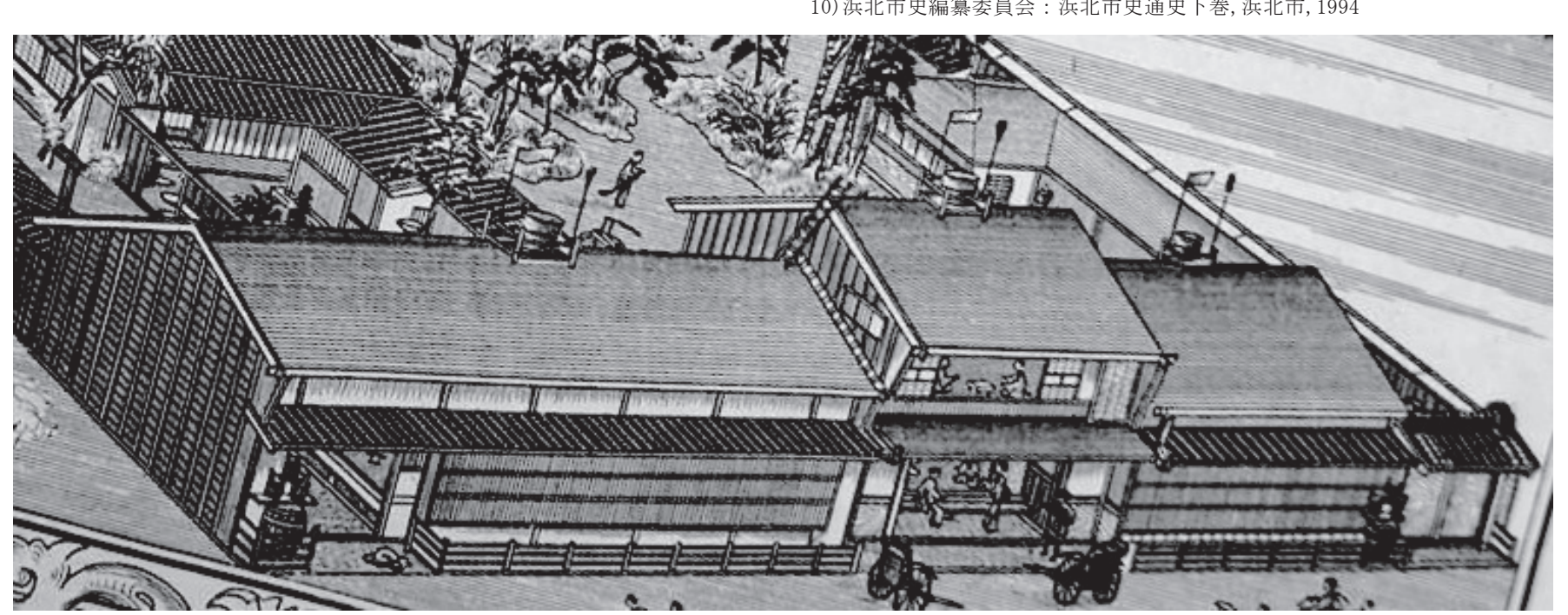

図 6 内田正邸 診察所拡大図 (『静岡県明治銅版画風景集』より抜粋) 
11) 静岡県 : 静岡県史通史編 3 近世 1 , 静岡県, 1996

12) 二村悟: 横浜における静岡茶の輸出と日除けの発生について, 日本建築学 会計画系論文集, No. 558, pp. 265〜270,2002.8

13) 不破正仁: 明治期の関東地方における屋敷林の樹木構成パターンとその分 布銅版画分析をもとにして, 日本建築学会計画系論文集 第 74 巻, No. 638, pp. 855〜862, 2009. 4

\section{注}

注 1) 貞二は、号を乾隈といい、水野藩の儒員八木正路にしたがい、大雄庵の 楚州に漢学を学び、江戸に出て、朝川善庵の門に入り、さらに塩谷岩陰に も学び、岩陰塾の塾頭となった人物である。また、蘭学を修め、当時の眼 科の大家土生の門に入り学び、郷里の浜松に帰り開業した。貞二の生存期 間については諸説ある。文献 4, p. 899 によれば、明治 32 年 (1899) 5 月 2 日 73 歳没と記載され、また文献 6, p. 47 によれば、文化 8 年 (1811) 生まれ、 明治 32 年に 73 歳没とされる。しかし、本研究に取り上げた『明治年中雜 録 参』の明治 18 （1885）年 3 月 26 日の自筆の原文によれば、「立忠寺二 於テ小栗宮崎両翁二逢フ小栗七十二宮崎六十七余七十五(以下略)」とある ことから、明治 32 年(1899) 5 月 2 日没から計算して 89 歳没となる

注 2) 全部で 437 図の銅版画が掲載されており、その内訳は明治 25 年刊行の 『日本博覧図・静岡県・初篇』228図と、明治 26 年刊行の『日本博覧図・ 静岡県・後篇』200 図(他に番外 9 図) の合計 437 図である。そのうち重複 掲載された 68 図を除くと、全部で 369 種類の銅版画が収録されている。

注 3) 文献 6,p. 46 によれば、『明治年中雜録』には、近代医学の育成に大き な貢献をもたらしたとされる、ドイツ人の医学者ベルツ博士が浜松を訪れ た際に、内田家で歓迎した様子が記録されている。

注 4) 内田家は江戸時代から続く医家の家系であり、貞二には正太郎(正)、周 平 (遠湖)、萬平、勉平の四子があり、長男の正は明治 22 年 (1889)に初代町 長に就任している。

注 5) 松屋山萬福寺は、浜松市中区八幡町に現存する曹洞宗の寺院である。

注 6) 筆者撮影。『明治年中雜録 拾参』は欠失。

注 7)いつ建屋が消滅したのかは定かではないが、文献 9 によれば昭和 12 年 6 月新町国道 1 号線拡幅以前のものとされる「明治末、大正、昭和初期、新町 住民図」中で、所在地に内田家の記載が確認できない

注 8$)$ 明治 28 年 2 月発行の地図『遠江國敷知郡濱松町全圖』の新町部分に、「医 師 内田正」と明記されている。

注 9) 文献 13 の、同著者による日本建築学会大会学術講演梗概集 (九州) 2007 年 8 月号『明治期銅版画に描かれる屋敷林の特徵 - 静岡県の農家が描かれ たものを対象としてー』pp. 437〜438 では、『静岡県明治銅版画風景集』 を用いた考察を行い、ソテツが前近代から当地区に存在する特徴的樹木構 成である可能性が指摘されている。

注 10) 文献 12 に基づく。

注 11) 文献 1 に基づく。

注 12) 図 4 に記された宅地図は、上部が東海道沿となる。

注 13) 画工の調査が行われた明治 24 年 8 月当時の推定見取図で、北敷地図は 図 4 の宅地寸法に基づき、南敷地は奥行を 20 間として作成した。

注 14）『明治年中雜録 武』明治 16 年 2 月 25 日の原文「我宅地々券相續人 正名二改ムル願書二月廿五日頃夕印シ戸長々澤氏迄出ス」による。

注 15）『明治年中雜録』の記載内容には、資産に関する記述も見られ、貞二 の家計簿的な役割もしていた。特に、造園に関する記録が多く掲載されて いるため、貞二の担当は庭園を主としていたと考えられる。また、明治 27 年 1 月 25 日の原文に「正児先ズ中亭擴張习嘱ス」とあることから正が屋敷工 事を担当していたと考えられる。

注 16）『明治年中雜録 壹』明治 14 年 10 月 31 日の原文「左官定十月三十一 日ヨリ来リ倉壁修繕二従事ス壱人工三拾五銭」十一月二日迄三人工作料 金壱円五銭酒銭五銭附シ渡ス」による。

注 17）『明治年中雜録 壹』明治 15 年 4 月 20 日の原文「離亭天井 四月二十 日桑吉張リ始ム」による。

注 18）『明治年中雜録 壹』明治 15 年 5 月 18 日の原文「左官定信両人五月十 八日来リ離堂天井下壁大津塗本舎東壁中塗大津北半 7 塗ル同十九日信壱人 来リ塗畢ル」による。

注 19）『明治年中雜録 武』明治 16 年 9 月以来の原文「左官用事 流シ棚脇 離亭西简持座 倉東瓦縫 倉東壁補 用心井塵辟輪 湯殿タタキ 湯殿シ キイ下 倉庇鼠穴 倉前石カケ縫 梨タタキ補 楼南蜂穴 離亭北上トイ 流し池」による。

注 20）『明治年中雜録 武』明治 16 年 11 月 11 日の原文「左官定十一月十一 ヨリ来リ倉壁修覆」による。
注 21)「元目桜」は[表 5 ]の 4 月 15 日の原文に書かれている桜のことである。 内田家に使われた植木は主に近隣の私邸庭園からの移植や、山から採取し たものであるが、桜の呼称に地名である「元目」をつけている。

注 22)「仮山」とは、庭園の景として土を盛って造られた山の総称である。 注 23)「溝東」の位置は不明である。

注 24) 銅版画の「土蔵」の西側に小門が描かれていることから、この倉とは「土 蔵」と考えられる。

注 25）『明治年中雜録 漆』明治 23 年 3 月 16 日の原文「三月十六日舟越寺櫻 及ビ野口山椒 移シ櫻八新亭北椒八小屋北二植二櫻價五拾銭山椒價拾銭」 による。

注 26) 明治 22 年春から内田家が催した花宴の招待客は、内田正が浜松町長就 任時期に、町政に深く関与した人物が多く名を連䄈ており、内田家の庭園 は社交場として活用されていたと推察される。

注 27）『明治年中雜録 漆』明治 23 年 6 月 20 日の原文「タ>キ六月二十日廿 一日隱居浴室及ビ北簷下玄関ノ地敲成」による。

注 28) その他に、『明治年中雜録 漆』明治 23 年 6 月 8 日の原文「(前略) 此 時正八不在母八本舎二居余八隠居二在テ阿準ノ告ゲヨ待チ(以下略)」があ る。また、『明治年中雜録 漆』明治 24 年 1 月 18 日の原文に「十八日夜靑 木我隠居二宿ス」とある。

注 29）『明治年中雜録 拾』明治 27 年 1 月 25 日の原文「大工五三郎廿七年一 月廿五日来テ我家土蔵修繥习議シ正児先ヅ中亭擴張习嘱ス」による。

注 30）『明治年中雜録 拾』明治 27 年 3 月 21 日の原文「中亭南補小室廿七年 三月廿一日一匠来起工 (陰暦二月十五日也) 廿九日立柱」による。

注 31）『明治年中雜録 拾式』明治 28 年 11 月 14 日の原文「廿八年十一月十 四日立具寅习呼ビ中亭南室二間半四本引ノ障子ヨ註文ス」による。

注 32) 原文には、工事建物の名称が記されていないが、注 29 の原文によれば、 正が土蔵修繕について大工五三郎と議論しており、また、伊豆石を使用し ていることから、明治 28 年 7 月の修繕工事は「土蔵」の工事と推定される。

注 33 )『明治年中雜録 拾肆』明治 31 年 1 月 17 日の原文「三十一年一月十七 日左官定等土蔵ノ舊表壁习削リ中塗二従事ス」による。

注 34）『明治年中雜録 拾肆』明治 31 年 9 月 21 日の原文「九月廿一日錺勝男 持チ来リ日ク道總亜鉛引銕板長五尺幅三尺物廿四枚價金廿武円四拾銭也卜 是レ西方雪院屋上葺料也」と、明治 31 年 10 月 30 日の原文门十一年十月三 十日屋根勝組等来少聚遠楼莫換二従事入 (以下略)」による。

注 35)「聚遠楼」の名称は、明治 24 年 2 月 2 日の原文「松島氏内友山鋮三君来 リ此夜松島氏八聚遠楼二宿ス」に記載が確認できる。

注 36）診察所が門長屋より内側に設置される事例は『静岡県明治銅版画風景

集』の「静岡縣敷知郡白脇村三島醫士藤田茂齋」などに見られる。

注 37)『明治年中雜録 漆』明治 23 年 6 月 8 日の原文「渠来リ奥倉ノ楼阿夫 佐ノ居ル処へ上ル(以下略)」の「楼」から二層の建物であることが理解でき る。銅版画の南敷地の西塀沿いの倉の二階東壁には空の描写が見られる。

注 38）『明治年中雜録 漆』明治 23 年 6 月 18 日の原文には「又三人来り柳 名残ヨリ楓ヨ作佐ヨリ移シ俱二厨前二植ユ」とあり、銅版画の描写にも煙突 のある建物前に柳が確認される。

注 39）『明治年中雜録 拾武』明治 29 年 9 月 18 日頃の原文「大工五三郎廿九 年九月十八日頃夜来リ裏門外一宅家屋工事习談ズ」による。

注 40）『明治年中雜録 拾式』明治 29 年 10 月 12 日の原文「廿九年十月十二 日裏門外新宅地新井习檕ツ田戋由組二命ズ」による。

注 41）『明治年中雜録 陸』明治 22 年 5 月 21 日の原文「敷知郡濱松町新町十 八番地 高橋桑吉印」による。

注 42) 『明治年中雜録 伍』明治 21 年 3 月 12 日の原文「(前略) 萬福寺廊及ビ 小室高橋桑吉受普請諸材諸工料金拾八円佛方ノ内へ預リ此日阿夫佐二命ジ 仕舞ハシム此金桑吉へ渡ス左記ノ如シ 廿一年三月十一日一金六円也桑 吉河岸行二付先ヅ我家二テ取換へ渡ス同月十五日一金四円五拾銭桑吉へ 渡ス(以下略)」による。

注 43）「百里園」とは、三方原の開拓地の茶園造成にともない、地元の有力者 で設立した製茶工場である。工場の敷地内には樹木が植栽され、その様子 を『静岡県明治銅版画風景集』の銅版画に見る事ができる。『明治年中雜 録 別』明治 24 年 9 月 1 日の原文に「九月一日又三人来以上三個日ニテ松 ヨ洗シ畢ル因テ二日ヨリ百里園ニ往ク」とあり、文中の「三人」とは庭平・大 安・小安を指す。

注 44）『明治年中雜録 壹』明治 14 年 11 月 7 日の原文「中坪疎籬十一月七日 午后ヨリ平兵衛来リ余卜共二野口ニ往キ竹 7 伐ル此日平兵衛餘㫡 7 以テ庭 中整頓」や、『明治年中雜録 漆』明治 23 年 4 月 1 日の原文「四月一日大島 櫻苗 別宅二移シ(以下略)」により、別宅の庭園や、貞二の実家である野口 町の庭園に出入りしていた様子が確認される。 